\title{
Modelling the Relationships of Service Recovery Satisfaction, Destination Image and Post-Trip Behaviour Intention
}

\author{
Mahadzirah Mohamad ${ }^{1}$, Ahmad Rusdi Abdullah², Abdul Manan Ali² \& Ridzuan Yacob ${ }^{2}$ \\ ${ }^{1}$ Faculty of Business Management and Accountancy, Universiti Sultan Zainal Abidin, Gong Badak Campus, \\ Kuala Terengganu, Terengganu, Malaysia \\ ${ }^{2}$ Faculty of Management and Economics, Universiti Malaysia Terengganu, Kuala Terengganu, Terengganu, \\ Malaysia \\ Correspondence: Mahadzirah Mohamad, Faculty of Business Management and Accountancy, Universiti Sultan \\ Zainal Abidin, Gong Badak Campus, 21300 Kuala Terengganu, Terengganu, Malaysia. Tel: 06-012-9876158. \\ E-mail: mahadzirahmd@unisza.edu.my
}

Received: May 23, 2013

Accepted: June 13, 2013

Online Published: July 26, 2013

doi:10.5539/ibr.v6n8p113

URL: http://dx.doi.org/10.5539/ibr.v6n8p113

\begin{abstract}
The purpose of the study was to establish the effects of service recovery on the image of the destination and post-trip behaviour intention. The causal relationship between the image of the destination and post-trip behaviour intention was also ascertained. A hypothetical model was proposed illustrating the relationships among these constructs. Four hypotheses were formulated and tested using structural equation modelling on survey data collected from 168 international tourists visiting Malaysia. The empirical findings reveal that hotel service recovery has direct effects on destination image and post-trip behaviour intention. In addition, the study suggests that there is a relationship between destination image and post-trip behaviour intention. Generally, Malaysia's destination image was perceived as positive by the respondents. The study reveals that international travellers experienced a trip to Malaysia as one which can be truly adventurous, as it not only offers the opportunity to have a glimpse at wildlife in their natural habitat, the country is also blessed with many places of natural beauty. This paper uncovers the importance of the local hotel service-recovery practices and proposes that destination management office should collaborate with them. This is to ensure that concerted efforts can be devised to encourage dissemination of positive word-of-mouth and intention to revisit among tourists who experienced failures with hotel service deliveries.
\end{abstract}

Keywords: service recovery, destination image, behaviour intentions, Malaysia

\section{Introduction}

Globally, Kim, Holland and Han, (2012) argue that the tourism industry is the fastest growing economic sector. Reflecting the afore-mentioned argument, the tourism sector ranks second only to manufacturing as a contributor to the Malaysian Gross Domestic Product (GDP), despite being a relatively new sector (Tourism Malaysia, 2008; Tourism Malaysia, 2009; Tourism Malaysia, 2010). The industry is becoming extremely competitive as new players enter the market with creative strategies (Kuenzel \& Katsaris, 2009). During the period between 2001 and 2011, foreign tourists arrival demonstrated an unstable and declining pattern of growth rates (Tourism Malaysia, 2013), signaling the obvious need for some drastic steps to be taken to ensure a more steady future development as the country pursues its target of being among the top ten in the global tourism receipts (Tenth Malaysia Plan 2011-2015(2010). Chen and Tsai, (2007) suggest that a tourist's choice of a destination is influenced by the destination image. Consistent and clear destination image is crucial to sustain the destination's competitive advantage. Malaysia is facing destination image inconsistency (Amran, 2004) and is having the problem of maintaining a consistent image for a long enough period of time to reinforce the country's image (Abdul Kadir, 2010). The situation is further illustrated through the slogans and themes used in Malaysia's image communications from 1990 until 2011. Malaysia started to sell the "natural" resources by using the slogan "To know Malaysia is to love Malaysia" in 1990 (Badaruddin, 2009). The theme "Malaysia Truly Asia", focussed on the colours, flavours, sounds, sights of Asia, was launched in 1999 and retained until today (Abdul Kadir, 2010). In 2007, Malaysia again organised Visit Malaysia Year using the slogan "Malaysia Welcomes the World" to portray Malaysia's image as a friendly destination (Tourism Malaysia, 2007). Recently, "Malaysia-Asia's Business Event 
Hub" was introduced to communicate Malaysia as an easy place to do business (Malaysia Convention \& Exhibition Bureau, 2011). Therefore, it is imperative to investigate the image held in the mind of tourists as an image-identification process can figure out the most representative objects and descriptors of the destination and design promotional tools consistent with the established images. According to Gover et al. (2007), travel behaviour is significantly influenced by successful marketing communication strategies promoting the destination image, which further illustrates that destination image has an influence on pre-trip behavioural intention.

Bhargava (2009) defined the tourism industry as consisting of "a collection of activities, services and industries that delivers a travel experience, as well as transportation, accommodations, eating and drinking outlets, retails shops, entertainment businesses, activities, facilities and other hospitality services offered for individuals or groups that are travelling away from home". Moreover, the consumption of tourism services, which is described to be mainly as experiential, can be discerned only after consumption or during consumption or during the "moment of truth" (Zeithmal et al., 2013). Positive post-visit destination image leads to favourable outcomes such as satisfaction and destination loyalty (Chi \& Qu, 2008). The fact that tourists at a destination would "consume" a combination of locally provided experiences, products and services, concurs with the proposition that destination marketing is multifaceted in nature (Tanja Dmitrovic et al., 2009). A high degree of integration is thus required amongst the multitude of service providers, be it taxi drivers, hoteliers, waiters or the different elements of the local attraction (Buhalis, 2000). The experiences staying at a hotel to a certain extent affect the total tourists' holiday experiences at a travel destination. Usually, when tourists are away from home, their major needs would comprise needs for accommodation, in addition to food and beverages; and transportation. Like other organisations in the sevice sector, hotel service deliveries are mostly labour intensive. In such a situation, delivery of most of the services require a high degree of interaction between the service-providing employees and the hotel guests. The hotel service delivery is often cited as an example of simultaneous service production and consumption, which leads to guests' assessments of service quality occurring during the process of delivering the service or "moment of truth". Moreover, the nature of simultaneous production and consumption of services entails less room for "zero defects" service deliveries which guarantee employees' service delivery would be free from mistakes and meet guest's expectation (Ahmad Rusdi et al., 2011). Service failures occur when service-delivery performance falls short of guests' expectations and most often lead to customer dissatisfaction. The situation calls for effective service-recovery strategies to regain customer satisfaction and retain their loyalty (Zeithaml, et al., 2013). Studying hotel service recovery satisfaction among tourists is crucial to ascertain its unexplored implications on destination image and loyalty. Kuenzel and Katsaris (2009) suggest that justice theory is the underlying theory to illustrate that destination image can be affected by the different aspects of hotel's service recovery. Therefore, this paper specifically examines the effects of hotel service-recovery on tourists' perception of destination image and post-trip behavioural intention, whilst treating destination image as a mediating variable.

\section{Conceptual Framework and Research Hypothesis}

Zeithmal et al. (2013) defined service recovery as the actions taken by the service providers to fix service failures. The tourist's pre-trip destination image would clearly have an influence on the ultimate destination chosen and post-trip destination image affects the post-trip destination loyalty (Kuenzel \& Katsaris, 2009). Moreover, these authors stressed that the effect of hotel service-recovery process on the image of a destination has not received adequate attention by researchers and they proposed a model postulating that hotel service recovery has a link to the post-trip image of a destination. In addition, service-recovery strategies seek to retain existing customers. Destination image is identified by Tasci and Gartner (2007) as an independent variable that influences behavioural intention. In addition, studies such as Hunt (1975) and Pearce (1982) have illustrated that there is a positive relationship between destination image and behavioural intention. These findings are parallel to the earlier work of Bigne, Sanchez, and Sanchez (2001) who found that tourism image is the antecedent of perceived quality, satisfaction, intention to return and willingness to recommend the destination. Futhermore, Chen and Tsai (2007) suggest that destination image has both direct and indirect effects on behavioural intentions.

A travel destination can be considered as a tourism product (Yoon \& Uysal, 2005). However, it is argued that tourists' overall travel experience, consisting of a combination of local tourism products and services, affects the development of their post-trip destination image (Buhalis, 2000). Thus, instead of overall satisfaction, perceived attractiveness of a destination is the antecedent to destination loyalty (Um, Chon, \& Ro, 2006). The post-trip behavioural intention of the customers to revisit and the dissemination of positive word-of-mouth about a particular destination to others may be used to define customer loyalty. As such, it is the main aim of the present study to develop and empirically test a hypthothesised model of service recovery, destination image and loyalty.Thus, the study was conducted to meet the following objectives: 
1) To determine the influence of hotel service recovery on the post-trip destination image.

2) To ascertain the effect of hotel service recovery on destination loyalty.

3) To identify the influence of post-trip destination's image on destination loyalty.

Therefore, the study proposed the research hypotheses set out below:

H1: Hotel service recovery has a direct positive effect on destination loyalty.

H2: Hotel service recovery has a direct effect on destination image.

H3: Destination image has a direct effect on the destination loyalty.

H4: Destination image mediates the relationship between hotel service recovery and destination loyalty.

\section{Method}

\subsection{Scope of the Study}

The respondents of this study were the international tourists visiting Malaysia for holiday or attending to business dealings. Moreover, according to Mill and Morisson (1985) they stayed for a minimum of one day and not more than one year to qualify them as tourists of a travel destination. In addition, they should experience some degree of service failures during their stay at the respective hotels. Data collection was conducted during the peak periods of the international tourist travelling season to Malaysia: July and December 2010, and March 2011, subject to the approval of the Malaysian airport authority.

\subsection{Measurement Tools}

A preliminary questionnaire was developed following the development of an initial items pool and was submitted to an expert panel, consisting of eight members, including academics and practitioners, to test content validity. A pilot study was conducted among 30 foreign tourists to assess the content validity, reliability, comprehension and estimated time required by the respondents to fill out the questionnaire. The revised questionnaire contained four major sections. The first section is made up of 18 items and attempts to measure guests' satisfaction with respect to service recovery strategies, which were adapted from the Lewis and McCann (2004). The effectiveness of the service recovery strategies used to compensate for the identified service failures such as "slow check-in", "unfriendly employees" and "poor equipment" were then measured based on the guest's satisfaction level. The strategies were categorised into Correction, Explanation, Apologies, Compensation, and Hotel did nothing. The questions incorporated a 10-point scale ranging from 1 as highly dissatisfied to 10 as highly satisfied. This study followed a multi-attribute approach of measuring destination image in which various common attributes were indentified and incorporated into an instrument (Tasci, 2007; Castro et al., 2007). The second section of the questionnaire contains quantitative items measuring Malaysia's image which were adapted from the work of Echtner and Ritchie (1993). These items were measured using a 10-point agreement-disagreement scale. Number 1 indicates strongly disagree and 10 designates strongly agree. Investigation of the tourist customer loyalty (post-trip behavioural intention) was carried out in the third part of the questionnaire using a 10-point scale ranging from 1 as not at all likely to 10 as extremely likely. The items used for measuring customer loyalty were adapted from Zeithaml et al. (1996). Lastly, the demographic data of the respondents are collected via questions contained in the final part of the questionnaire.

\subsection{Sampling Procedures}

Prior to the collection of data, permission was obtained from the Malaysian airport authority (Malaysia Airport Berhad) to distribute questionnaires to the departing tourists at Kuala Lumpur International Airport (KLIA) and Low Cost Carrier Terminal (LCCT). Data were collected using personal interviews performed by trained interviewers. Self-administered questionnaires were distributed to boarding tourists at the halls of the respective departure gates. A systematic sampling method was used to select respondents. Every $5^{\text {th }}$ intercepted respondent was selected after a random starting point. The collection of data took place over a period of four weeks. Out of 1051 respondents approached, only 303 were qualified to be included in the study as most of them did not experience hotel service failures during their current visit to Malaysia. After a data-cleaning process, only 168 useable questionnaires (representing 55\% response rate) were subjected for further analysis. Structural Equation Modelling (SEM) was applied to the dataset as the sample size meets the minimum requirement of cases to conduct SEM (Hair et al., 2010).

\section{Results}

The underlying dimensions of the constructs in the study were ascertained using exploratory factor analysis. Reliability analyses were conducted for service recovery, destination image and destination loyalty through the 
determination of Cronbach's alpha values. The analyses yielded Cronbach's alpha values of 0.96, 0.76 and 0.94 respectively (Table 1). Cronbach's alpha values of equal or greater than 0.7 are considered as an acceptable good indicator of reliability (Nunnally \& Berstein, 1994).Confirmatory factor analysis (CFA) was then used to ascertain the multidimensionality of the theoretical constructs before eventually applying structural equation modelling (SEM) to the data set to test the goodness-of-fit of the hypothesised model. In addition, path analysis was used to ascertain the relationships between variables in the proposed model.

\subsection{Profile of the Respondents}

The majority of the respondents involved in the study were mainly from Asian countries (27\%) mostly coming from India, Indonesia and China. European countries ranked second (25\%), with the majority of them coming from the United Kingdom, Netherlands, Germany and France. Oceania ranked third (22\%), tourists coming from countries such as Australia and New Zealand, followed by Middle East (11\%) mostly from Iran, United Arab Emirates (UAE) and Oman. A majority of the respondents (61\%) were made up of male tourists. As indicated by most respondents, holidaying $(80 \%)$ was identified as the main purpose of their visit to Malaysia and they were accompanied by spouse or friends. 44 percent of the respondents were comprised of travellers that visit Malaysia for the first time while while 56 percent were on returning trips. Of those returning, $19 \%$ and $15 \%$ were on their second and third trips respectively.

\subsection{Measurement Model}

CFA was employed using maximum likelihood estimation (ML) to establish confidence in the measurement model. The measurement's convergent validity was ascertained through construct reliability (CR) and average variance extracted (AVE). A reliability estimate of 0.6 is acceptable and an AVE value of 0.5 or higher is considered as adequate convergence (Hair et al., 2010). Table 1 illustrates the indicators' factor loadings are higher than 0.7 for all constructs, ranging from 0.78 to 0.98 , meeting the requirement of convergent validity. AVE values ranged from 0.68 to 0.95 , indicating constructs' strong convergent validity. Moreover, the values of Cronbach's alpha for all constructs, ranging from 0.76-0.96, showed strong internal consistency. Discriminant validity of the three constructs was established by examining the squared correlation estimates between each pair of the constructs and comparing them with the AVE of the respective constructs (Hair et al., 2010). Since none of the squared correlations exceeded the AVE estimates, the three constructs met the discriminant validity requirement.

Table 1. Confirmatory factor analysis

\begin{tabular}{|c|c|c|c|c|c|}
\hline Constructs & Items & Factor Loading & Cronbach's alpha & $\mathrm{CR}$ & AVE \\
\hline Service & Explanation(Exp) & 0.98 & 0.96 & 0.98 & 0.95 \\
\hline \multirow[t]{2}{*}{ recovery } & Apology (Apo) & 0.98 & & & \\
\hline & Correction (Cor) & 0.96 & & & \\
\hline Destination & A holiday in Malaysia is a real adventure (D16) & 0.78 & 0.76 & 0.87 & 0.68 \\
\hline \multirow[t]{2}{*}{ image } & Malaysia offers the chance to see wildlife (D27) & 0.84 & & & \\
\hline & Malaysia offers a lot in terms of natural scenic beauty (D33) & 0.85 & & & \\
\hline Destination & Disseminate positive word of mouth (B1) & 0.94 & 0.94 & 0.98 & 0.69 \\
\hline \multirow[t]{3}{*}{ loyalty } & Recommend others to visit Malaysia (B2) & 0.96 & & & \\
\hline & Encourage others to visit Malaysia (B3) & 0.97 & & & \\
\hline & Intention to revisit (B4) & 0.84 & & & \\
\hline
\end{tabular}

\subsection{Structural Model}

The structural model of the research is illustrated in Figure 1. The goodness-of-fit of the structural model is assesed using several accepted statistical indices such as Goodness-of Fit Index (GFI), adjusted Goodness-of Fit Index (AGFI), Tucker Lewis Index (TLI) and Comparative fit Index (CFI). For each of these statistical indexes, a value of 1 indicates that the model is perfect fit. (Byrne, 2001). There are supports that the hypothesised model acceptably fits the observed data. The cutoff normed Chi-square value should be less than 3.0 (Bollen, 1989) and the achieved normed Chi-square $(\chi 2 / d f=1.499)$ met the requirement. The RMSEA value of 0.055 indicated the structural model achieved adequate good-fit (Hu \& Bentler, 1999). GFI, AGFI, TLI and CFI values of 0.946, $0.908,0.988$ and 0.991 respectively also suggest that the suggested model adequately fits the data. This implies thatthis model as fitting the data adequately.

The tested model encompassed three latent variables: service recovery, destination image and destination loyalty. Service-recovery and destination image are manisfested by three underlying items. Finally, destination loyalty is 
manisfested by four items. These items are depicted in Table 1. The values of the path's coefficients for the full model are positive and significant ( $p$-value $<0.05$ ). The direct effect of service recovery on destination loyalty is $\beta$ $=0.35$ and it has a significant positive effect on destination loyalty $(\mathrm{p}<0.001)$. When destination image is included as the mediator variable into the model, the influence of hotel service recovery on post-trip destination loyalty is reduced $(\beta=0.13)$ and its effect on destination loyalty is significant $(\mathrm{p}<0.05)$. In this case, destination image partially mediates the relationship between hotel service recovery and post-trip destination loyalty (DL). The findings of the study show that there is positive significant relationship between hotel service recovery and destination loyalty; hotel service recovery and destination image; and destination Image and post-trip destination loyalty.

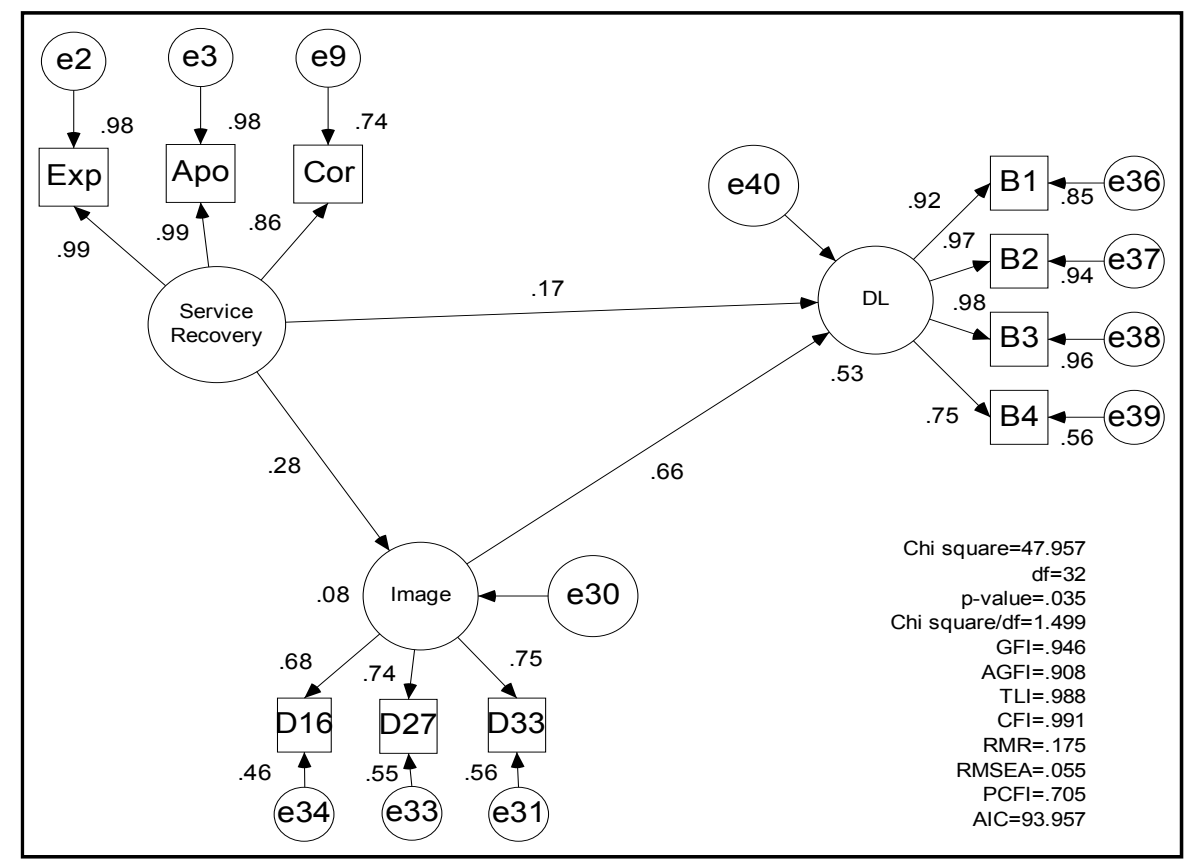

Figure 1. Structural model of hotel service recovery, destination image and post-trip destination loyalty

\section{Discussion}

In this empirical study, Structural Equation Modelling (SEM) was used to test a model that examines the relationships among hotel service recovery, destination image and destination loyalty. The resulting analysis supported Hypothesis 1, suggesting that there is a significant relationship between hotel service recovery and destination loyalty. Moreover, there is enough evidence to support Hypothesis 2 that proposed hotel service recovery has a direct effect on destination image. The study also failed to reject Hypothesis 3 that postulated destination image has a direct effect on the post-trip destination loyalty. The findings also supported Hypothesis 4 that proposed destination image mediates the relationship between service recovery and destination loyalty. Therefore, it can be concluded that hotel service recovery is the antecedent to destination image and destination loyalty. Post-trip destination loyalty is a consequence of hotel service recovery and destination image. This indicates that both hotel service recovery and destination image are important variables influencing destination loyalty. This finding supports the model postulated by Kuenzel and Katsaris (2009), which proposed that hotel service recovery influences a destination's image, which in turn influences destination loyalty.

The results of the study provided useful insights for the Malaysia Tourism Board in terms of a possible positioning strategy to promote Malaysia as a travel destination. The study lends support to the belief that Malaysia is perceived positively by internation tourists. Additionally, the study illustrates the perception amongst international tourists that Malaysia is a travel destination that promises to be an exciting adventure which not only offers the opportunity to see wildlife but also a lot in terms of natural scenic beauty. Creating memorable travel experiences based on nature-based tourism destination would provide competitive advantage and could distinguish Malaysia from its competing neibouring coutries. The positioning strategy should focus on Malaysia's natural scenic landscapes, which include beaches and tropical forests, offering adequate facilities to support adventure tourism and observe wildlife in its natural habitat. Some of the potential locations for scenic landscapes/adventure holidays are Lake Kenyir, Langkawi Geopark, Taman Negara, Mount Kinabalu Park and Perhentian Island. 
This study identified a market segment that visit Malaysia seeking for nature-based travel experience, an adventurous holiday and opportunity to see wildlife. Although urbanisation development is accelerating and important to the nation's economic growth, Malaysia should not portray on urbanised image to this segment of international tourists as they visit Malaysia to view the natural scenic beauty and experience an adventurous holiday. For example, it was noted by Badaruddin (2009) that building new theme parks do not help in strengthening the destination image of Malaysia and this study empirically proves his argument, especially to this group of market segment. Islands, sandy beaches and tropical forests of Malaysia are important assets that could offer natural scenic beauty and adventurous holidays as expected by travellers and became the unique selling proposition to attract international tourists to Malaysia. Moreover, the study empirically suggests that visitors' satisfaction with efforts undertaken by hoteliers to recover service failures has a direct effect on destination image, and has a significant effect on tourists' intentions to revisit and disseminate positive word-of-mouth. Understanding the relationship between service-recovery process and image of a destination would highlight the importance of the local hotel service-recovery practices and collaborate with them to improve efforts enhancing the post-visit destination image among tourists who experienced failures with hotel service deliveries. The findings of this study illustrated different aspects of tourists' perception of Malaysia's image that centre around the natural scenic beauty of Malaysia. Hence, the study proposes positioning Malaysia to this segment of tourists, as nature-based tourism while simultaneously offering an adventurous holiday.

\subsection{Limitation of the Research}

Readers are cautioned to read the article in light of its limitations. Nonetheless, these limitations could be treated as potentials for future research. First and foremost, the measurement of image was only conducted among current tourists visiting Malaysia and excluded potential tourists. Accordingly, the findings of the study only capture the post-trip destination image among foreign tourist and disregard the formation of a destination's pre-visit image among potential tourist. Secondly, respondents were asked to respond to the selected service failures identified in the questionnaires, but no room was provided for them to express their satisfaction to service failures not listed in the questionnaires. Consequently, the findings of the present study do not deal with other forms of service failures that may be experienced by hotel guests. Finally, the respondents were selected among those who could understand the English Language since the questionnaires was prepared in English. Thus, the limited ability to generalise the findings of the study is undeniable. Therefore, future research should be undertaken in view of these limitations.

\section{References}

Abdul, K. L. D. (2010). Malaysia as an imagined destination the selling points. Sintok: Universiti Utara Malaysia Press.

Ahmad, R. A., Mahadzirah, M., \& Safiek, M. (2011). Examiningthe structural relationships of service recovery, destination image and behavioural intentions of foreign tourists: aproposal. International Journal of Business and Management Studies, 3(2).

Amran, H. (2004). Policy and Planning of the Tourism Industry in Malaysia. Proceedings, The $6^{\text {th }}$ ADRF General Meeting. Bangkok, Thailand (pp. 1-21).

Badaruddin, M. (2009). Image of Malaysia as a Destination-A Review. Retrieved from http://www.hbp.usm.my/tourism/Papers/paper_image.htm

Bigne, J. E., Sanchez, M. I., \& Sanchez, J. (2001). Tourism image, evaluation variables and after purchase behaviour: Interrelationship. Tourism Management, 22(6), 607-616. http://dx.doi.org/10.1016/S0261-5177(01)00035-8

Bhargava, M. (2009). Tourism: Issues and perspectives. New Delhi, India: Raj Publications.

Bollen, K. A. (1989). Structural Equations with Latent Variables. New York: Wiley.

Byrne, B. M. (2001). Structural equation modelling with AMOS: Basic concepts applications. Mahwah, New Jersey: LawranceErlburm Associates Publishers.

Buhalis, D. (2000). Marketing the competitive destination of the future. Tourism Management, 21, 97-116. http://dx.doi.org/10.1016/S0261-5177(99)00095-3

Castro, C., Armario, E., \& Ruiz, D. (2007). The influence of market heterogeneity on the relationship between a destination's image and tourists' future behaviour. Torism Management, 28, 175-187. http://dx.doi.org/10.1016/j.tourman.2005.11.013

Chen, C. F., \& Tsai, D. C. (2007). How destination and evaluative factors affect behavioral intentions? Tourism 
Management, 28, 1115-1122. http://dx.doi.org/10.1016/j.tourman.2006.07.007

Chi, C. G., \& Qu, H. (2008). Examining the structural relationships of destination image, tourist satisfaction and destination loyalty: an integrated approach. Tourism Management, 29, 624-636. http://dx.doi.org/10.1016/j.tourman.2007.06.007

Echtner, C. M., \& Ritchie, J. R. (1993). The measurement of destination image: an empirical assessement. Journal of Travel Research, 31(4), 3-13. http://dx.doi.org/10.1177/004728759303100402

Govers, R., Go, F. M., \& Kumar, K. (2007). Promoting tourism destination image. Journal of Travel Research, 11(2), 199-217.

Hair, J. F. Jr., Black, W. C., Babin, B. J., \& Anderson, R. E. (2010). Multivariate Data Analysis (7th ed.). New Jersey: Prentice Hall International, Inc.

Hu, L. T., \& Bentler, P. M. (1999). Cutoff criteria for fit indexes in covariant structure analysis: conventional criteria versus new alternative. Structural Equation Modeling: A Multidisciplinary Journal, 6(1), 1-55. http://dx.doi.org/10.1080/10705519909540118

Hunt, J. D. (1975). Image as a factor in tourism development. Journal of Travel Research, 13(3), 1-7. http://dx.doi.org/10.1177/004728757501300301

Kim, S., Holland, S., \& Han, H. (2012). A structural model for examining how destination image, perceived value, and service quality affect destination loyalty; a case study of Orlando. International Journal of Tourism Research. http://dx.doi.org/10.1002/jtr.1877

Kline, R. B. (2005). Principles and Practice of Structural Equation Modelling (2nd ed.). New York: Guilford Press.

Kuenzel, S., \& Katsaris, N. (2009). A critical analysis of service recovery processes in the hotel industry. TMC Academic Journal, 4(1), 14-24.

Lewis, B. R., \& McCann, P. (2004). Service Failure and recovery: evidence from the hotel industry. International $\begin{array}{lllll}\text { Journal of Contemporary Hospitality } & \text { Management, } & \text { 16(1), } & \text { 6-17. }\end{array}$ http://dx.doi.org/10.1108/09596110410516516

Mahadzirah, M., Abdul Manan, A., \& NurIzzati, A. G. (2011). A structural model of destination image, tourist satisfaction and destination loyalty. International Journal of Business and Management, 3(2), 167-177.

Mahadzirah, M., Ahmad, R. A., \& Safiek, M. (2012). Tourist's evaluations of destination image and future behaviour intention: the case of Malaysia. Journal of Management and Sustainability, 2(1), 181-189.

Malaysia Convention \& Exhibition Bureau. (2011). Positioning Malaysia as Asia's business events hub. Retrieved from

http://corporate.tourism.gov.my/images/news/Brand\%20Launch\%20\%Nov\%202011\%-\%20ENG\%20-\%20I nt'l.pdf

Mill, R. C., \& Morisson, A. (1985). The Tourism System. Hemel Hempstead: Prentice Hall.

Nunally, Y. J. C., \& Berstein, J. H. (1994). Psychometric Theory (3rd ed.). New York: McGraw-Hill.

Pearce, P. L. (1982). Perceived changes in holiday destinations. Annals of Tourism Research, 9, 145-164. http://dx.doi.org/10.1016/0160-7383(82)90044-5

Tanja, D., Ljubica, K. E. C., Tomaz, K., Maja, M. B. I., Irena, O. E., \& Vesna, Z. A. (2009). Conceptualizing tourist satisfaction at the destination level. International Journal Of Culture, Tourism and Hospitality Research, 3(2), 116-126. http://dx.doi.org/10.1108/17506180910962122

Tasci, A. D. A. (2007). Assessment of factors influencing destination image using a multiple regression model. Tourism Review, 62(2), 23-30. http://dx.doi.org/10.1108/16605370780000311

Tasci, A. D. A., \& Gartner, W. C. (2007). Destination Image and its functional relationship. Journal of Travel Research, 45(4), 413-425. http://dx.doi.org/10.1177/0047287507299569

Tenth Malaysia Plan 2011-2015. (2010). Kuala Lumpur: Percetakan National Malaysia Berhad.

Tourism Malaysia. (2007). Annual Report 2007. Kuala Lumpur: Tourism Malaysia.

Tourism Malaysia. (2008). Malaysia key performance indicators 2008. Malaysia: Tourism Malaysia, Ministry of Tourism.

Tourism Malaysia. (2009). Malaysia key performance indicators 2009. Malaysia: Tourism Malaysia, Ministry of 
Tourism.

Tourism Malaysia. (2010). Malaysia key performance indicators 2010. Malaysia: Tourism Malaysia, Ministry of Tourism.

Tourism Malaysia. (2013). Fact and Figure. Retrieved from http://www.tourism.gov.my/corporate/research.asp

Um, S., Chon, K., \& Ro, Y. (2006). Antecedents of revisit intention. Annals of Tourism Research, 33(3), 1141-1158. http://dx.doi.org/10.1016/j.annals.2006.06.003

Yoon, Y., \& Uysal, M. (2005). An examination of the effects of motivation and satisfaction on destination loyalty; a structural model. Tourism Management, 6(1). http://dx.doi.org/10.1016/j.tourman.2003.08.016

Zeithaml, V. A., Berry, L. L., \& Parasuraman, A. (1996). The behavioral consequences of service quality. Journal of Marketing, 60(2), 31-46. http://dx.doi.org/10.2307/1251929

Zeithmal, V. A., Bitner, M. J., \& Gremler, D. D. (2013). Services Marketing: Integrating Customer Focus Across the Firm. New York: McGraw-Hill.

\section{Copyrights}

Copyright for this article is retained by the author(s), with first publication rights granted to the journal.

This is an open-access article distributed under the terms and conditions of the Creative Commons Attribution license (http://creativecommons.org/licenses/by/3.0/). 